\title{
Menelusuri Gagasan Tafsir Tematis Muhạmmad Bāqir al-Ṣadr
}

\author{
Lilik Ummi Kaltsum
}

Fakultas Ushuluddin UIN Syarif Hidayatullah Jakarta

lilikimzy@yahoo.com

\begin{abstract}
The product of thematic tafsir is not only related to certain themes, but also must be directly linked to the problem of reality. This article presents a figure of thematic tafini, in which he puts more emphasis on solving problems of society and not only focuses on the text of the Qur'ān. He is Muhammad Bāqir al-Șadr. In addition, besides his major work on philosophy, Falsafatuna, he is also renowned a reformer in the field of methods of interpretation (tafsir).
\end{abstract}

Keywords: Thematic tafsīr, reality, text.

Abstrak: Produk dari tafsir tematis tidak hanya berhubungan dengan tema-tema khusus yang berkaitan dengan teks an sich melainkan juga harus berkelindan dengan problem-problem sosial yang riil. Tulisan ini menyajikan seorang tokoh tafsir tematis, yaitu Muhammad Bäqir alSadr, yang tidak hanya berfokus kepada teks-teks al-Qur'än namun juga kepada jalan keluar dari problem masyarakat. Selain dikenal karya besar falsafatnya, yaitu Falsafatunā, Muhammad Bāqir al-Sadr juga seorang reformis dalam bidang tafsir.

Kata Kunci: Tafsir tematis, realitas, teks. 


\section{Pendahuluan}

Salah satu kegelisahan utama penafsiran al-Qur'ān adalah adanya kesenjangan antara produk tafsir yang hadir dan dikonsumsi oleh masyarakat dengan problematika sosial yang dihadapinya. Kebutuhan masyarakat saat ini tidak hanya pada kandungan makna dan hukum saja sebagaimana yang mewarnai tafsir-tafsir klasik, tetapi lebih pada penafsiran yang realistis dan aplikatif. Al-Qur'ān yang sejak awal pewahyuannya telah bersentuhan dengan realitas sosial yang melingkupinya, sering diposisikan sebagai "bahasa langit" yang absolut, sehingga terkesan cukup dengan pemaknaan atau penafsiran tunggal untuk semua zaman. ${ }^{1}$ Perkembangan zaman yang terus berubah dihadapkan dengan penafsiran teks yang monoton inilah yang melahirkan sebuah kesenjangan. Kesenjangan antara teks dengan persoalan-persoalan kemanusiaan dapat diartikan sebagai "kegagapan" atau ketidakmampuan umat Islam untuk mengaitkan ajaran-ajaran Islam dalam al-Qur'ān dengan isu-isu kemanusiaan, seperti kemiskinan, diskriminasi, eksploitasi, dan kebodohan. ${ }^{2} \mathrm{Di}$ sinilah urgensi dari upaya mendialogkan teks al-Qur'ān dengan realitas sosial yang dinamis. Upaya yang dilakukan tentunya membutuhkan sebuah pembaharuan dalam penafsiran.

Al-Qur'ān bukan sebagai kitab hukum atau lahan untuk keterampilan para filolog juga bukan sebagai legitimasi madzhab teologis. Al-Qur'ān bukanlah spekulasi teoritis, monograf-monograf gramatikal atau kutipan-kutipan ilmiah di luar bimbingan al-Qur'ān itu sendiri. Setiap Muslim harus meyakini bahwa al-Qur'ān bukan sekedar dibaca secara lafzìyah tetapi harus selalu direnungkan kandungan maknanya, sehingga al-Qur'ān benar-benar berfungsi sebagai petunjuk kehidupan. ${ }^{3}$

Proses pewahyuan al-Qur'ān tidak diwahyukan sekaligus (30 juz), sebagaimana kitab suci lainnya, tetapi diwahyukan secara bertahap yang bersentuhan dengan problem realitas saat itu. ${ }^{4}$ Oleh karena itu upaya untuk menemukan jawaban terhadap permasalahan realitas saat ini akan menemui kesulitan jika hanya mengandalkan penafsiran yang runtut dari al-Fātiḥah sampai al-Nās. Celah inilah yang ditawarkan oleh metode maw $\bar{x}_{\bar{u}} \bar{\imath}$ atau tematis yaitu menafsirkan al-Qur'ān dengan cara mengumpulkan ayat-ayat al-Qur'ān terkait 
tema-tema tertentu tanpa terikat dengan tartīb muṣhafì , dan dikaji secara cermat dan mendalam kemudian dikorelasikan antar ayat sampai pada akhirnya melahirkan sebuah konsep pemaknaan yang komprehensif dan sistematis. ${ }^{5}$

Melalui metode tafsir tematis ini diharapkan masyarakat modern tidak lagi disibukkan dengan pembahasan yang tidak diperlukan, tapi lebih mudah menemukan jawaban dari tantangan zamannya sehingga lebih optimal dalam memosisikan al-Qur'ān sebagai kitab petunjuk kehidupan. Penggunaan metode ini akan melahirkan tafsir yang beragam, karena tuntutan kondisi, waktu dan tempat masingmasing mufassir tidak akan sama. Problem masa lalu tidak akan sama dengan problem masa kini dan problem saat ini juga tidak akan sama dengan masa yang akan datang. Demikian juga permasalahan di suatu tempat atau negara tidak akan sama dengan problematika di tempat atau di negara yang lain. ${ }^{6}$

Tulisan ini mengetengahkan tokoh tematisyang lebih menekankan pada pemecahan problem masyarakat bukan hanya terfokus pada teks al-Qur'ān, sebagaimana yang telah dilakukan oleh tokoh tematis yang lain. Artinya, produk tafsir tematis bukan sekedar konsep al-Qur'ān terkait tema-tema tertentu tetapi juga harus dikaitkan langsung dengan problem realitas. Tokoh tersebut adalah Bāqir al-Ṣadr. Di balik ketokohannya di bidang falsafat dengan karyanya Falsafatunā, ia juga termasuk pembaharu di bidang metode tafsir.

\section{Bāqir al-Șadr: Si Miskin yang Pandai}

Muḥammad Bāqir al-Ṣadr dilahirkan pada hari Kamis tanggal 25 Dzū al-Qa'dah 1353 H. bertepatan dengan 1 Maret 1935 M. di Kāẓimīyah dalam keluarga besar yang religius dan termasyhur di dunia Syı̄'ah. Ayahnya yaitu Haydar lahir di Samarrā pada tahun 1309 H./1891 M. Murid dari Āyatullāh al-Hāìiñ al-Yazdī ini meninggal dunia di Kāẓimīyah tahun 1356 H./ 937 M. dengan meninggalkan seorang isteri, dua orang putra yaitu Ismāīl al-Șadr dan Bāqir al-Ṣadr serta seorang putri, Bint al-Hudā. Kendati seorang marja’ terkemuka, Haydar, ayah Bāqir, meninggal dunia dalam keadaan miskin. Hingga lebih dari sebulan setelah sang ayah meninggal dunia, keluarganya masih terus mengalami kesulitan memenuhi kebutuhan makan 
sehari-hari, kānū häàiān fì luqmah al-syay.' ${ }^{7}$

Intelektualitas yang tinggi dan kehidupan yang miskin merupakan dua unsur penting yang sangat memengaruhi konteks pendidikan Șadr. Kesulitan ekonomi yang dihadapi keluarga pada awal meninggal Haydar juga dialami oleh bayi Bāqir al-Șadr. Haydar memang tidak mewariskan harta benda tetapi nilai-nilai kepribadian yang mulia dan semangat keilmuannya telah terwarisi dalam jiwa putra-putri Haydar. Ini terlihat dalam diri Bāqir, meski dalam keterpurukan ekonomi keluarga, ia tetap semangat untuk belajar setiap hari. Bāqir dikenal sebagai pribadi yang tulus ikhlas, tawādu', zuhud, perkataannya sesuai dengan perbuatannya, penuh belas kasih dan sabar. Sepeninggal ayahnya, Bāqir diasuh oleh ibunya dan paman dari garis ibunya yang bernama Murtadá 'Alī Yāsīn serta Ismāīl kakak tertuanya (w. 1388 H./1968 M). Selain pengaruh ayahnya, kepribadian serta semangat hidup Bāqir juga dipengaruhi oleh kakek buyutnya yaitu Șadr al-Dīn al-Āmulī (w. 1264 H./1847 M.), dan kakeknya, Ismā'īl (w. 1338 H./1919 M.) ${ }^{8}$

Bāqir mengawali sekolah dasarnya di Muntadā al-Naṣr al'Ibtidāīyah di kota Kāẓimīyah.' Pada usia ini Bāqir telah mampu mengaji kitab Ma'álim al-Ușül di bawah bimbingan kakak tertuanya Ismāîl al-Ṣadr, dan pada usia 11 tahun ia telah mampu melahirkan sebuah buku dengan judul Risālah fì al-Mantiq. ${ }^{10}$ Keunggulan Bāqir dalam bidang ușül al-fiqh ini semakin tajam ketika pada tahun 1365 H./1945 M. ia dan keluarganya pindah ke kota Najf. ${ }^{11}$ Meski Bāqir tidak secara langsung berguru kepada ketiga ulama besar ușūl al-fiqh Syī'ah yaitu Shaykh Muhammad Husayn al-Isfahānī, Muhammad Husayn al-Nāīn̄ì dan Âqā Ḍiyāa al-'Irāqī, namun pemikiran tokohtokoh ilmu ușūl tersebut ditransformasikan lebih detail oleh guru utamanya yaitu Abū al-Qāsim al-Khū'î́12 dan Muhammad Riḍā 'Alī Yāsīn. Pola pikir tokoh inilah yang sangat memengaruhi dan membuka wawasan berpikir Bāqir. ${ }^{13}$

Abū al-Qāsim al-Khūi menekankan pentingnya mengetahui dan memahami sejarah pewahyuan al-Qur'ān agar dapat mengaplikasikan ketetapan-ketetapan al-Qur'ān secara tepat dalam masyarakat Muslim kontemporer. Baginya, pemahaman al-Qur'ān berikut latar pewahyuannya akan memerkuat dan memermudah seseorang dalam 
mengaji teori-teori istinbāt hukum dan menetapkan hukum (fiqh). Bersama kedua gurunya tersebut Bāqir menyelesaikan kajian ilmu ușül fiqh dan fiqh di Najf selama 14 tahun (1365-1379 H.) sampai akhirnya mencapai otoritas berijtihad dalam bidang ușül fiqh dan fiqh. Penyelesaian studi ini dinilai luar biasa karena pada umumnya proses pembelajarannya minimal selama 16 tahun. ${ }^{14}$

\section{Rumusan Metode Tafsir Tematis Bāqir al-Ṣadr}

Tujuan mendasar dari upaya pembaharuan Bāqir adalah mengungkap secara dalam dan mendasar teori-teori keislaman baik dalam bidang sejarah, ekonomi, politik, sosial dan lain-lain. Teoriteori tersebut langsung dihubungkan dengan kehidupan manusia sehingga dapat diposisikan sebagai problem solving dari setiap permasalahan yang muncul. ${ }^{15}$

Bāqir al-Ṣadr, sebagaimana tokoh mawdī‘ $̇$ lainnya, meyakini bahwa metode tematis merupakan solusi dari berbagai kekurangan yang ada pada tafsir-tafsir sebelumnya yang menghasilkan kesimpulan yang parsial atau tajzìì. ${ }^{16}$ Menurut Bāqir beberapa konsep Qur'ānī yang dihasilkan dari metode analitis (tahlì $\bar{\imath})$ dengan jelas telah menimbulkan konflik-konflik keagamaan. Ini karena pada umumnya mufassir akan merasa cukup jika telah memahami suatu konsep dari ayat al-Qur'ān tertentu yang bisa melegitimasi madzhabnya, untuk selanjutnya memroklamirkan dan menjaring pengikut sebanyakbanyaknya. Hal ini banyak terjadi dalam isu-isu ilmu kalām (teologi) seperti dikotomi jabarīyah dan qadarīyah. Sebenarnya, konflik-konflik ini bisa dihindari jika mufassir yang menggunakan pendekatan analitis bersedia mengambil langkah-langkah lebih jauh dan tidak membatasi diri pada mengumpulkan sejumlah ayat yang saling mendukung terhadap suatu pemahaman ayat tertentu. Dengan demikian, metode maw $\mathbf{u}_{\bar{u}} \bar{\imath}$ atau upaya menafsirkan al-Qur'ān dengan cara memilah dan memilih ayat-ayat al-Qur'ān untuk menemukan konsep Qur'ānī yang utuh dan tidak parsial tentang beberapa problematika hidup adalah sebuah keharusan. ${ }^{17}$

Untuk memerjelas posisi metode mawdī'ì yang ditawarkan Bāqir al-Ṣadr dengan tokoh mawdū' $\grave{\imath}$ lain, sub bab berikut ini akan menjelaskan batasan pengertian metode maw dū $\bar{\imath}^{\prime}$ menurut Bāqir dan 
langkah-langkah penelitiannya. Dua poin inilah yang menjadikan

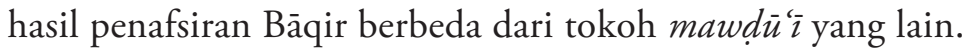

\section{Metode Mawdī' 'i}

Menurut Bāqir Istilah mawdū'ì yang dikenal saat ini tidak ditemukan dalam karya-karya ulama terdahulu. Tafsir mawdī' merupakan istilah baru yang dipergunakan oleh ulama dan peneliti modern untuk menggali makna-makna al-Qur'ān. Bentuk baru dalam metode tafsir ini diharapkan akan memberikan nuansa baru dalam memahami firman Allah. Penafsiran melalui pengelompokan tematema yang tersebar dalam al-Qur'ān ini sekaligus akan menunjukkan kemu'jizatan al-Qur'ān. Al-Qur'ān bukan hanya diposisikan sebagai teks yang bisu tetapi ia benar-benar dijadikan sebagai pedoman hidup yang mampu merespon keresahan masyarakat di sepanjang zaman, sebagaimana yang pernah diikrarkan oleh sahabat Alī ibn Abī Tālib bahwa al-Qur'ān adalah al-șirāt al-mustaqìm (jalan yang lurus) yang tidak akan dibelokkan oleh hawa nafsu, tidak akan terkontaminasi dengan ucapan-ucapan manusia, tidak akan puas para ulama untuk selalu meneliti dan mengajinya dan tidak akan habis keajaiban atau kemu'jizatannya. ${ }^{18}$

Menurut Bāqir istilah maw $\operatorname{du}_{\bar{u}} \hat{\imath}$ memiliki tiga macam makna: pertama, bermakna "objektifitas" lawan kata dari "subjektifitas" (al-dzātīyah) dan bermakna "berada dalam sebuah ruang" (attahayyuz). Mawdī'ì dalam makna ini menunjukkan sikap amanah dan konsistensi dalam pembahasan ini, serta sikap berpegang teguh pada ketentuan-ketentuan keilmuan yang berlandaskan kepada realitas peristiwa dalam membahas setiap perkara dan kejadian yang sama, tanpa terpengaruh sedikit pun oleh perasaan dan pendirian pribadinya dan tidak memihak dalam menentukan hukum-hukum serta hasil-hasil yang diperoleh dari pembahasannya. Menurut Bāqir istilah mawdī' $\bar{\imath}$ dalam pengertian seperti ini dapat dipakai baik metode mawdī'ì maupun metode tajzì $\bar{\imath}$.

Kedua, istilah maw $\bar{u}_{\bar{u}} \bar{\imath}$ memiliki makna memulai pembahasan dari tema realitas sosial kemudian didialogkan dengan ayat-ayat alQur'ān sehingga ditemukan jawaban yang tepat dari realitas tersebut. Karena itulah, seorang mufassir yang menggunakan metodologi tafsir 
mawd $\bar{u}^{\prime} \bar{\imath}$ harus memusatkan perhatiannya pada tema-tema yang berkaitan dengan kehidupan, aqidah, sosial dan fenomena alam, di samping ia juga harus mengusai permasalahan-permasalahan seputar tema tersebut yang didapatkan melalui pemikiran manusia, mengetahui solusi permasalahan tersebut yang disumbangkan oleh pemikiran manusia, serta mengetahui apa-apa yang tercatat dalam sejarah sebagai pertanyaan dan poin-poin yang belum dijabarkan. Setelah itu barulah seorang mufassir memulai tanya-jawabnya dengan al-Qur'ān, mufassir bertanya dan al-Qur'ān menjawab. Dengan demikian diharapkan mufassir dapat mengetahui sikap al-Qur'ān terhadap tema yang ditetapkan.

Metode penafsiran seperti ini juga dikenal dengan metode penyatuan $($ tawhì $\bar{\imath} \bar{\imath})$. Hal itu karena metode ini menyatukan antara eksperimen-eksperimen manusia dengan ayat-ayat al-Qur'ān. Ini tidak berarti bahwa metode ini lebih mendahulukan eksperimeneksperimen manusia dari ayat-ayat al-Qur'ān, akan tetapi manyatukan antara keduanya dalam satu alur pembahasan dengan harapan dari alur pembahasan tersebut dihasilkan suatu kesimpulan tentang sikap al-Qur'ān yang dapat dijadikan sebagai sikap Islam terhadap setiap eksperimen dan kesimpulan pemikiran yang dilakukan manusia. ${ }^{19}$

Ketiga, istilah mawdī $\grave{\imath}$ dimaksudkan untuk segala sesuatu yang dinisbatkan kepada suatu tema. Seorang mufasir memilih tema tertentu, kemudian mengumpulkan ayat-ayat al-Qur'ān yang berkaitan dengan tema tersebut dan menafsirkannya, serta berusaha menyimpulkan pandangan al-Qur'ān dari ayat-ayat yang berkaitan dengan tema tersebut.

Metode penafsiran seperti ini juga dapat disebut dengan metode tawhìdì dalam pengertian penyatuan kandungan ayat-ayat al-Qur'ān yang berkaitan dengan tema tertentu dalam satu pandangan. ${ }^{20}$ Ada juga yang menyebutnya dengan taqtîi ${ }^{i}$ artinya mufassir hanya menampakkan atau menekankan kandungan ayat yang sesuai dengan tema dan kurang fokus pada penjelasan lain yang tidak terkait tema meskipun dalam satu ayat. ${ }^{21}$

Menurut Bāqir metode ini diharapkan akan memberikan nuansa baru dalam memahami firman Allah. Penafsiran melalui pengelompokan tema-tema yang tersebar dalam al-Qurān ini 
sekaligus akan menunjukkan kemu'jizatan al-Qur'ān. Al-Qur'ān bukan hanya diposisikan sebagai teks yang bisu tetapi ia benar-benar dijadikan sebagai pedoman hidup yang mampu merespon keresahan masyarakat di sepanjang zaman, sebagaimana yang pernah ditegaskan oleh sahabat Alī ibn Abī Țālib bahwa al-Qur'ān adalah al-șirāt almustaqim yang tidak akan dibelokkan oleh hawa nafsu, tidak akan terkontaminasi oleh ucapan-ucapan manusia, tidak akan puas para ulama untuk selalu meneliti dan mengajinya dan tidak akan habis keajaiban atau kemu'jizatannya. ${ }^{22}$

Dari ketiga pengertian ini, istilah mawdī' $\bar{\imath}$ dengan makna pertama yaitu objektif tidak termasuk dalam inti pembahasan ini, karena dalam pengertian pertama ini tidak terdapat perbedaan antara tafsir mawd $\bar{u} \hat{\imath}$ dan tafsir tajzìì. Sikap objektif memang harus diupayakan oleh mufassir baik dengan metode mawdī' $\bar{\imath}$ atau tajzì $\hat{\imath}$. Dengan demikian, yang menjadi pokok pembahasan adalah istilah mawdī' $\bar{\imath}$ dengan makna kedua dan ketiga.

Inilah letak perbedaan Bāqir dari tokoh mawdī $i ̀$ lainnya. Tafsir maw $\bar{u}_{\bar{u}} \bar{\imath}$ Bāqir disebut juga dengan tawhìd $\bar{\imath}$ karena ada dua upaya yang harus diupayakan yaitu mengumpulkan atau menyatukan ayatayat yang terkait tema, dan tema-tema tersebut harus juga menyatu dengan realitas masyarakat, sehingga tidak terkesan teks tafsir mawdī'i terpisah dari problem masyarakat yang ada. Cara pendefinisian seperti ini tidak ditemukan dalam literatur lain yang juga mengaji tafsir mawd̄̄ $\hat{\imath}^{23}$

Bāqir menyebutkan bahwa mawd̄̄' $\bar{\imath}$ merupakan ide baru ulama kontemporer yang belum ditemukan masa sebelumnya. Hal ini bisa dipahami dari penjelasannya bahwa kehadiran metode mawdī' adalah sebagai penutup kekurangan metode tajzì $\bar{\imath}$ tanpa penjelasan adanya benih-benih pada masa Rasul. ${ }^{24}$ Penafsiran al-Qur'ān dengan al-Qur'ān yang telah sering dilakukan oleh Rasulullah merupakan upaya mengetahui makna ayat terkait dengan tugas Rasul sebagai penyampai sekaligus penjelas dari wahyu tersebut, karena al-Qur'ān harus dipahami secara menyeluruh yaitu menyatukan semua ayat yang terkait. Upaya tersebut belum dapat disebut sebagai tafsir dengan metode mawd $\bar{u}^{\top} \bar{\imath}$ sebagaimana pengertian saat ini. Demikian juga upaya ulama-ulama yang berusaha mengumpulkan ayat-ayat 
yang semakna, sebagaimana yang telah disebutkan tidak sama dengan tafsir maw dū $\grave{\imath}$ baik dari segi tujuan maupun metodologinya. ${ }^{25}$

Bagi Bāqir kajian tematis atau tafsir mawdūì bukan sekedar mengumpulkan persoalan-persoalan serupa atau memiliki kemiripan antara satu dengan yang lainnya sebagaimana karya-karya yang telah disebutkan, tetapi mengetengahkan persoalan atau tema-tema realitas kehidupan dan mengaji secara mendalam menurut cara pandang alQur'ān. ${ }^{26}$ Dengan kata lain tafsir bermetode mawdī $\bar{\imath}$ benar-benar format baru yang belum ditemukan pada masa sebelum tahun 1960an apalagi pada masa Rasulullah.

Menurut Bāqir upaya menyatukan teks al-Qur'ān dengan realitas yang terus berkembang inilah yang menjadi kekuatan metode mawdūì. Ia menyatakan bahwa anugerah atau petunjuk-petunjuk Allah yang terkandung dalam al-Qur'ān tidak terbatas, sedangkan tafsir harfìyah bersifat terbatas dan berkekurangan. Oleh karena itu, kehadiran tafsir mawdī'ì berusaha untuk menjelaskan ketakterbatasan al-Qur'ān. Metode ini mampu membuktikan bahwa al-Qur'ān adalah catatan tentang masa lampau, dan juga memuat pengetahuan masa yang akan datang. Ia adalah obat bagi penyakit-penyakit. Melaluinya bisa diketahui pandangan Ilahi mengenai semua peristiwa di bumi.

Dengan alasan itulah Bāqir mengharuskan proses penafsiran dimulai dari pembacaan realitas dan berakhir pada analisis naṣs alQur'ān. Hal ini akan menjadikan tafsir mawdū 'ì mampu menciptakan perkembangan yang cepat, karena pengalaman manusia membuatnya berkembang. Demikian juga adanya jawaban atau problem solving yang dihasilkan dari tafsir mawdū' terarah. Jika al-Qur'ān dikaji dalam lingkup pengalaman manusia, maka penemuan-penemuan baru akan dihasilkan, tidak sekedar normatif tetapi realistis dan aplikatif. ${ }^{27}$ Problematika masyarakat yang terus berkembang hanya bisa dijawab dengan konsep-konsep atau pandangan-pandangan al-Qur'ān melalui kajian tematis tersebut. ${ }^{28}$

Adanya kekuatan yang dimiliki tafsir mawdī' $̇$ tersebut semakin memerkokoh urgensi tafsir mawdū $َ \bar{\imath}$ di dalam ranah kajian al-Qur'ān. Hal ini sekaligus menunjukkan bahwa secara metodologi, metode tafsir maw $\bar{u}_{\bar{u}} \hat{\imath}$ lebih sempurna dan dapat dipertanggungjawabkan. Kelemahan atau kekurangan yang biasa disandarkan kepada tafsir 
maw $\bar{u}_{\bar{u}} \bar{\imath}$ adalah terkait dengan tingkat keahlian mufassirnya dan tingkat kekuatan mufassirnya dalam menekan subjektifitasnya bukan dari sisi metodologinya. Di sinilah arti pentingnya persyaratan seorang mufassir sehingga penafsiran yang dihasilkan tidak menyimpang dari ajaran Islam ataupun hanya sebagai legitimasi kepentingan tertentu. Menurut Bāqir ada empat syarat yang harus dimiliki mufassir yang salah satunya adalah bahwa seorang mufassir harus memahami dan menafsirkan al-Qur'ān sesuai dengan ketentuan agama Islam. Ia harus meyakini bahwa al-Qur'ān bukanlah kitab ilmu pengetahuan tertentu tetapi kitāb Ilāhì yang diturunkan untuk memberikan petunjuk menuju kehidupan yang lebih baik dan diridaiNya.

\section{Cara Kerja Metode Tematis Bāqir al-Șadr}

Secara global Bāqir menjelaskan bahwa ada dua tahap yang harus dikerjakan seorang mufassir mawdī' $\mathrm{\imath}$ yaitu pertama, meneliti problematika realitas yang terjadi. Mufassir mengumpulkan data-data sebanyak-banyaknya terkait dengan gagasan-gagasan dan pengalaman-pengalaman manusia. Kedua, mendialogkan permasalahan-permasalahan yang telah diidentifikasikan tersebut kepada al-Qur'ān. Melalui dialog yang mengharuskan keaktifan mufassir ini, metode tafsir mawdū $̌$ akan menghasilkan kesimpulan yang komprehensif tentang pandangan-pandangan al-Qur'ān yang berbasis pada pengalaman-pengalaman manusia. Dua tahap inilah yang ia istilahkan dengan yubda'u min al-wāqi' wa-yantahì ilá alQur'ān. ${ }^{29}$

Prinsip minal-wāqi iláal-naș bukan bertujuan untuk mefokuskan pembahasan pada realitas ( $\left.a l-w \bar{a} q i^{\circ}\right)$ dan mengesampingkan pesan dari naṣs al-Qur'ān, sehingga sangat tampak subjektif. Akan tetapi, analisis realitas tersebut diposisikan sebagai pengayaan modal bagi mufassir ketika berdialog atau menelusuri ayat-ayat terkait. Pembacaan realitas bukan untuk mendukung asumsi subjektif mufassir tetapi justru untuk meningkatkan objektifitas penafsiran karena mufassir dengan sikap aktifnya memersilahkan al-Qur'ān untuk berpendapat sendiri dengan cara mengeluarkan sebanyak-banyaknya ayat yang terkait. ${ }^{30}$

Secara detail dan sistematis Bāqir belum sempat merumuskan

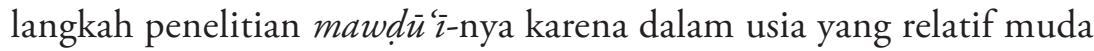


dan masih produktif ia meninggal dunia di bawah rezim Saddam

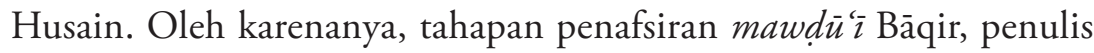
melacak dan mengembangkannya dari ceramahnya tentang metode tafsir mawdū'ì yang kemudian dikumpulkan dan ditulis dalam alMadrasah al-Qur'ānīyah. Tahapan penafsiran yang dimaksud adalah sebagai berikut: ${ }^{31}$

\section{Penentuan tema melalui pembacaan realitas.}

Penekanan awal dari metode mawdū'ì yang berprinsip min alwāqi ila al-nașs adalah menjawab atau memberikan solusi dari berbagai problematika sosial. Ini karena masalah sosial selalu menempati posisi penting dan telah mendorong umat manusia, dalam gelanggang perjuangan intelektual maupun politik, untuk melibatkan diri dalam suatu perjuangan yang penuh dengan liku-liku kehidupan. Pemecahan problematika sosial harus diprioritaskan karena Islam bukan sekedar agama doktrin tetapi Islam adalah tonggak kehidupan. Dalam kehidupan tidak akan pernah sepi dari ragam peristiwa dan permasalahan, maka sudah seharusnya Islam dengan kitab sucinya alQur'ān harus mampu menjawab setiap problema kehidupan. ${ }^{32}$

Menurut Bāqir, Islam bukanlah sekedar agama dogmatis atau agama yang hanya membahas hubungan manusia dengan Tuhannya, tetapi juga memedulikan hubungan kemanusiaan. Islam adalah manhaj lil-hayāh atau pedoman hidup yang mampu memberikan cara-cara menghadapi kehidupan. Islam merupakan agama yang berusaha menyelaraskan antara hubungan manusia dengan Tuhan dan manusia dengan sesamanya. Islam hadir di samping sebagai agama hidayah yang akan membimbing umatnya menuju jalan yang benar, juga sebagai agama revolusi, yang berusaha memberikan perubahan-perubahan yang baik dalam aspek kehidupan. Islam tidak mengasingkan diri dari kehidupan duniawi tetapi justru ia hadir memberikan petunjuk-petunjuk yang dapat digunakan sebagai solusi atas berbagai problema kehidupan umatnya sampai akhir zaman. ${ }^{33}$

Dengan demikian, Islam bukan agama yang terpisah dari realitas masyarakat, tetapi Islam hadir untuk memberikan solusi-solusi masalah sosial. Problem apapun yang dihadapi, hendaknya didialogkan atau dicari jawabannya dari prinsip-prinsip atau nilai-nilai yang telah 
diajarkan agama Islam. Tidak ada satu pun alasan untuk memisahkan agama dari kehidupan sosial. Pengalaman sosial dijadikan langkah awal dalam pembuatan tafsir mawdī̄ adalah eskpresi dari salah satu sistem yang telah dipraktikkan dan telah diterapkan selama bertahun-tahun. Dari penelitian realitas dengan berbagai problem dan cara pandang masyarakatnya yang telah dilakukan, seorang mufassir mulai menetapkan tema yang akan dibahas atau problem yang akan dicarikan jawabannya dalam alQurān. ${ }^{34}$

Oleh karena itu, sebelum memilih sebuah pokok masalah sosial atau mengenai kehidupan dunia, seorang mufassir yang akan menggunakan metode maw $\bar{x}_{\bar{u}} \bar{\imath}$ harus mencurahkan cukup perhatian pada gagasan-gagasan dan pengalaman-pengalaman kehidupan manusia, mengumpulkan data yang diperlukan dan mengajinya secara mendalam. Mufassir mawdù $\bar{\imath}$ harus mengenal masalah-masalah yang berkaitan serta solusi-solusinya sepanjang yang disarankan oleh pemikiran manusia. Artinya, mufassir bukan sekedar melihat fenomena masyarakatnya tetapi juga memahami sikap mereka ketika menghadapinya. ${ }^{35} \mathrm{Hal}$ ini sekaligus akan tampak adanya penyatuan (tawhì $\bar{i}$ ) antara problem kehidupan dengan petunjuk Qur'ānī. Meski demikian, mufassir tidak boleh menundukkan al-Qur'ān hanya untuk kepentingan-kepentingan subjektif.

Pengalaman sosial dijadikan starting point dalam pembuatan tafsir mawd $\bar{u} \hat{\imath}$, karena pengalaman sosial adalah eskpresi dari salah satu sistem yang telah dipraktikkan dan telah diterapkan selama bertahun-tahun. Pengalaman tentang sistem feodal dan kapitalis, misalnya, telah diterapkan selama bertahun-tahun dan diakui sebagai sistem yang terbaik untuk menangani masalah pada waktu itu, pada kenyataannya kini perlu dipertanyakan kembali apakah sistem tersebut benar-benar menjadi sistem terbaik yang tidak merugikan orang banyak ataukah sebagai sistem yang mengangkat harkat martabat manusia? ${ }^{36}$

Setelah membaca dan menganalisis problematika realitas, seorang mufassir diharuskan menetapkan tema besar yang akan diteliti. Sebagaimana dalam penelitian keilmuan, penentuan tema ini bertujuan agar penelitian atau penafsiran dapat terarah dan tidak 
keluar dari frame tema yang telah ditentukan. ${ }^{37}$ Sedangkan penetapan judul dilakukan setelah membaca dan menganalisis teks al-Qur'ān sehingga ditemukan judul yang tepat sesuai dengan tema besar yang akan dianalisis.

\section{Berdialog dengan al-Qur'ān ${ }^{38}$}

Setelah tema pembahasan ditentukan sebagaimana yang dijelaskan pada tahap pertama, langkah kedua adalah berusaha mendialogkan permasalahan tersebut dengan al-Qur'ān. Sahabat 'Alī, berkata, "Persilahkanlah al-Qur'ān berbicara."39 Ini adalah ungkapan paling indah dalam menggambarkan tugas tafsir mawdī' yang digambarkan sebagai dialog dengan al-Qur'ān dengan cara mengajukan pertanyaan-pertanyaan kepadanya mengenai setiap masalah, agar menemukan jawaban-jawabannya. Dalam hal ini Bāqir memberikan langkah-langkah sebagai berikut:

Pertama, membaca al-Qur'ān secara keseluruhan berulang-ulang. Sudah selayaknya sebagai kitab suci, al-Qur'ān harus selalu dibaca baik lafaznya maupun kandungan maknanya. Mufassir mawdī' $\bar{\imath}$ tidak cukup jika hanya berdasarkan Mu'jam al-Mufahras li Alfäz al-Qur'ān ataupun al-Mufradàt fì Gharìb al-Qur'ān. Kitab tersebut hanya sebagai pembantu pelacakan ayat. Karena hasil yang akan ditemukan adalah konsep atau sikap al-Qur'ān terhadap problem social, bukan penelitian ayat perayat semata, maka semakin banyak al-Qurān dibaca, akan semakin banyak mutiara pemahaman ayat yang akan mewarnai pola pikir seseorang dan akan memengaruhi sekaligus menyerahkannya ketika hendak berdialog dengan al-Qur'ān.

Kedua, menelusuri dan mengumpulkan ayat-ayat al-Qur'ān yang terkait dengan tema. Penelusuran dilakukan selengkap mungkin. Tidak hanya terkait dengan satu, dua, dan tiga kata. Misalnya, tentang keadilan, term yang dilacak bukan sekedar ' $a-d-l$ tetapi juga $q-s-t, z-l-m$ dan ayat-ayat lain yang mendukung meskipun tidak menggunakan tiga kata tersebut. Semakin banyak seseorang membaca al-Qur'ān, semakin mudah seseorang untuk menelusuri ayat-ayat yang satu tema. Seorang mufassir harus mampu melacak seluas mungkin jawaban-jawaban dari pertanyaan-pertanyaan yang telah dipersiapkan ketika membaca realitas. 
Pelacakan ayat seperti ini akan lebih memerkaya atau ayat-ayat yang dikumpulkan lebih lengkap karena mufassir di samping bertujuan membangun konsep komprehensif juga harus mampu melacak seluas mungkin jawaban-jawaban dari pertanyaan-pertanyaan yang telah dipersiapkan ketika membaca realitas. Jika pembacaan teks al-Qur'ān kurang maksimal maka ia akan kesulitan menelusuri jawaban dari pertanyaan yang ia lontarkan atau bisa juga ia akan salah dalam menetapkan jawabannya. Di sinilah mufassir diposisikan sebagai peserta dialog yang dituntut aktif namun tetap menjaga ramburambu atau syarat-syarat mufassir sehingga tidak terjadi pemaksaan ayat. $^{40}$

Ketiga, masing-masing ayat tersebut dipahami satu persatu dengan bantuan tafsir tajzì̄ benar memahami terlebih dahulu kandungan makna ayat al-Qur'ān sebagaimana yang telah diungkap oleh tafsir klasik yang semuanya tersusun secara taḥlì $\bar{\imath}$, antara lain mufradāt. Setiap kitab-kitab tafsir pasti menjelaskan terlebih dahulu makna masing-masing kata dalam setiap ayat-ayat al-Qurān. Dalam hal ini Bāqir menekankan agar para penafsir atau peneliti memersilahkan al-Qur'ān berbicara sendiri tanpa ada campur tangan aktif dari peneliti. ${ }^{41}$

\section{Mengorelasikan antar ayat dan menglasifikasikannya.}

Setelah semua ayat yang terkumpul dipahami satu persatu kandungan maknanya, maka langkah selanjutnya adalah mengorelasikan antar ayat-ayat tersebut. Dengan pemahaman yang utuh terhadap kandungan makna ayat mufassir berusaha menghubungkan ayat satu dengan ayat yang lainnya. Kemudian ia mengelompokkan atau menglasifikasikannya sesuai dengan sub-sub tema bahasan.

\section{Menyusun dan melahirkan konsep Qur'ānī.}

Setelah pengelompokan ayat, langkah berikutnya adalah menyusun data-data tersebut dengan penuh ketelitian sehingga pada akhirnya dapat terwujud konsep Qur'ānī terkait dengan tema yang telah ditetapkan secara sistematis dan komprehensif sekaligus sebagai jawaban dari problem realitas yang telah ditentukan. 
Perlu ditekankan di sini bahwa pembuatan kerangka penelitian seharusnya setelah selesai memahami ayat-ayat yang telah dikumpulkan hasil dari dialog dengan al-Qur'ān, sehingga semua informasi-informasi al-Qur'ān tersebut dapat terangkum dalam kerangka penelitian. Jika outline sudah ada terlebih dahulu sebelum memahami penafsiran ayat, maka dikhawatirkan ada beberapa informasi ayat yang terabaikan. Di sinilah diperlukan kelihaian seorang peneliti mengolah dan menganalisis data atau ayat-ayat yang telah dikuasai kandungan maknanya untuk disuguhkan secara utuh dan sistematis.

Dengan demikian, bentuk tafsir mawdū' $\bar{\imath}$ yang sempurna adalah disajikan dalam bentuk utuh dan sistematis. Hitungan-hitungan ayat, Makki-Madanī dan hal-hal yang biasa disebutkan dalam tafsir tạ̣līli merupakan modal utama yang harus diolah sedemikian rupa, tidak harus ditulis secara eksplisit atau sebatas diperlukan untuk memerkokoh penjelasan tema utama.

\section{Posisi Metode Tafsir Tematis Bāqir al-Ṣadr}

Gagasan tafsir tematis Bāqir bukanlah gagasan tunggal yang tidak ada pembandingnya. Sebagaimana telah di singgung dalam pendahuluan, bahwa mengaji dan memahami al-Qur'ān secara tematis merupakan metode tafsir yang sesuai dengan kebutuhan zaman. Oleh karena itu, tematisasi al-Qur'ān juga telah dilakukan oleh tokoh tokoh selain Bāqir.

Secara garis besar metode tematis dari tokoh-tokoh tersebut dapat dibagi menjadi dua kelompok. Pertama, metode tematis yang proses penafsirannya berawal dari teks al-Qur'ān dan kurang memerhatikan perkembangan realitas, sebagaimana yang telah dilakukan oleh 'Abd al-Hayy al-Farmāwī dan para pendukungnya. Kedua, metode tematis yang berawal dari problema realitas, sebagaimana yang ditawarkan oleh Bāqir al-Ṣadr.

Seperti telah disebut, tokoh yang mendasarkan penafsirannya pada teks al-Qur'ān dan tidak menekankan pembacaan realitas terlebih dahulu adalah al-Farmāwī. Dalam karyanya al-Bidāyah fì alTafsìr al-mawdī'i ditemukan penjelasan bahwa penafsiran al-Qur'ān harus dimulai dari pembacaan, penelitian dan pengajian teks al- 
Qur'ān sampai menghasilkan pandangan atau sikap al-Qur'ān terkait tema tertentu. Wawasan al-Qur'ān tersebut kemudian disosialisasikan ke masyarakat sebagai pedoman untuk melangkah menuju masa depan lebih baik. Para mufassir yang memegang prinsip min al-naș ilā al-wāqi' ini berdasarkan keyakinan bahwa kesempurnaan agama dan kesempurnaan perjalanan hidup hanya dapat dicapai dengan pemahaman pengetahuan agama yang bersumber dari al-Qur'ān. ${ }^{42}$

Di samping itu, salah satu alasan para mufassir yang menerapkan prinsip ini adalah karena kajian tematisasi al-Qur'ān tidak hanya sebatas eksperimen manusia. Pesan-pesan atau pandangan alQur'ān tidak selalu ditemukan dalam perjalanan sejarah yang dapat diamati oleh mufassir. Keberadaan al-Qur'ān bukan hanya meluruskan atau korektor dari pengalaman-pengalaman manusia tetapi juga memberikan konsep al-Qur'àn yang komprehensif agar dapat dijadikan sebagai pedoman hidup. Realitas sosial tidak selalu bertentangan dengan nașs al-Qur'ān. ${ }^{43}$

Proses penafsiran yang berawal dari teks al-Qur'ān ini, oleh sebagian tokoh dinilai kurang mampu merespon kebutuhan masyarakat modern. Sebuah tafsir al-Qur'ān haruslah realistis, aplikatif dan bukan sekedar normatif-idealistis. Penafsiran al-Qur'ān harus berangkat dari problematika masyarakat yang ada.

Selain Bāqir, gerakan pembaharuan tafsir seperti ini juga dilakukan oleh Hassan Hanafī. Menurutnya, al-Qur'ān diwahyukan memang untuk memberikan solusi yang dapat dipahami dan diaplikasikan oleh masyarakatnya. Sebuah tafsir seharusnya berangkat dari perjalanan hidup yang secara riil dialami oleh mufassir. Penulisan tafsir bukanlah sebuah profesi atau barang komoditi melainkan pencarian makna atau petunjuk al-Qur'ān guna mengubah kondisi masyarakat menjadi lebih baik. Ukuran kebenaran tafsir seperti ini adalah kemampuannya dalam mengadakan perubahan dan efektifitas. ${ }^{44}$ Dengan demikian, sebuah penafsiran al-Qur'ān harus memiliki tujuan dan dapat bermakna dalam kehidupan bukan sekedar ḩarfìyah atau normatif.

Bagi Hanafí, penafsiran harus dapat menjawab problema kehidupan. Teks hanyalah sekedar alat sedangkan kehidupan nyata dinilai sebagai absolut dan yang perlu diperhatikan. Bahkan, jika teks tidak sesuai dengan kemaslahatan, maka kemaslahatanlah yang 
harus didahulukan. Menafsirkan berarti melakukan gerakan ganda: pertama dari teks menuju realitas (min al-nașs ilā al-wāqi), tahap ini yang diterapkan adalah prinsip-prinsip kebahasaan termasuk juga sejarah teks, dan kedua dari realitas menuju teks (min al-wāqi`ilā al-nașs). Tahap kedua ini prinsip yang digunakan adalah sensitivitas semangat zaman. Penafsiran sosiologis $\left(\right.$ ijtimā $\left.^{\prime} \hat{\imath}\right)$ seperti ini akan dapat menransformasikan penafsiran dari sekedar mendukung dogma agama menuju gerakan perubahan dan dari tradisi menuju modernisasi. ${ }^{45}$

Selain Hassan Hanafī terdapat beberapa nama yang juga dikenal sebagai pembaharu tafsir antara lain Fazlur Rahman, Arkoun, Nașr Hāmid Abū Zayd dan lain-lain. Meski secara terperinci terdapat banyak perbedaan di antara tokoh-tokoh tersebut, namun titik global persamaannya adalah "membumikan tafsir". Artinya, sebuah tafsir alQur’ān harus selaras dengan kebutuhan masyarakat zamannya bukan sekedar kumpulan norma-norma idealis.

\section{Simpulan}

Tulisan ini sesungguhnya hendak menegaskan bahwa metode tafsir tematis yang berawal dari analisis realitas dan berakhir pada analisis teks al-Qur'ān (mawdū'ì min al-wāqi'îlā al-nașs) dapat melahirkan pandangan al-Qur'ān yang komprehensif-sistematis dan realistis-aplikatif terkait tema-tema tertentu, bukan sekedar konsep normatif-idealis sehingga mampu menghadapi perubahan dan perkembangan zaman. Hasil penafsiran tematis yang berawal dari realitas ini sekaligus dapat menjadi solusi dan kritik terhadap problem realitas, sebagaimana yang ditawarkan oleh Bāqir al-Ṣadr.

Metode penafsiran al-Qur'ān akan terus mengalami perubahan dan perkembangan seiring dengan perubahan dan perkembangan zaman. Dengan kata lain, relativitas dan tentativitas tidak dapat dihindari dalam dunia interpretasi teks. Karena itu, tidak ada klaim kebenaran tunggal (oleh siapa pun) dalam dunia interpretasi teks, termasuk penafsiran al-Qur'ān.

\section{Catatan Akhir}

${ }^{1}$ Naṣr Ḥāmid Abū Zayd, Mafhūm al-Nașs Dirāsah fì 'Ulüm al-Qurāan (Beirut: 
Markaz al-Tsaqaī al-'Arabī, 1994 M.), 2-3.

2 M. Hilaly Basya, "Mendialogkan Teks Agama dengan Makna Zaman," dalam al-Huda, volume III, nomor 11, 2005, 10-11.

3 Muhammad Ibrāhīm Syarīf, Ittijāhāt al-Tajdìd fī al-Tafsīr al-Qur'ān alKarim $f_{i}$ Misrr, 185-187. Kegelisahan semacam ini telah dikhawatirkan oleh Rasulullah yang mengadu kepada Allah, "Ya Tuhanku, sesungguhnya kaumku telah mengabaikan al-Qur'ān ini," sebagaimana yang terekam dalam surat alFurqān/25:30.

4 Penjelasan terkait proses turunnya al-Qur'ān dapat dibaca lebih lanjut dalam beberapa literatur 'ulüm al-Qur'ān, antara lain al-Zarkasyī, Al-Burhān fì 'Ulūm al-Qur'ān, jilid 1, 45-47; Jalāl al-Dīn al-Suyūțị, al-Itqān fì 'Ulūm al-Qur'ān (Kairo: Dār Ihyā̄ al-Kutub al-'Arabīyah, 1980), jilid 1, 60-65; Muhammad 'Abd al-'Az̄ìm al-Zarqānī, Manāhil al-'Irfān (Beirut: Dār al-Fikr, t.t.), jilid 1, 50-53.

5 Kata maw $\bar{u}^{\prime}$ biasa diantonimkan dengan kata marfū'. Salah satu makna marf $\bar{u}$ ‘ adalah sesuatu yang diangkat, maka mawdū' berarti sesuatu yang diletakkan atau diturunkan. Oleh karena itu, dalam ilmu Hadìts dikenal dengan istilah hadìts marf $\bar{u}{ }^{\prime}$ dan mawdī' Hadīts marfü' berarti Hadīts yang terangkat, termuliakan yaitu yang disandarkan kepada Rasulullah, sedangkan hadìts mawdū' adalah Hadīts yang secara bohong disandarkan kepada Rasulullah atau biasa dinamai dengan Hadìts palsu. Artinya Hadìts tersebut tidak terangkat mulia tetapi diletakkan begitu saja dan diabaikan. Lih. Muhammad 'Ajjāj alKhațīb, Ușül al-Hadìts (Beirut: Dār al-Fikr, 1989), 355 dan 415. Sedangkan di dalam al-Qur'ān kata wad' terulang 24 kali yang kesemuanya tidak mengarah kepada makna buruk atau tercela. Al-Qur'àn lebih menggunakan kata tersebut dengan makna aslinya yaitu tempat atau meletakkan tanpa diarahkan pada sesuatu yang buruk, seperti tentang peletakan Ka'bah dalam surat Ālū 'Imrān/3: 96, timbangan dalam al-Raḥmān/55: 7 dan al-Anbiyā’/21: 47 juga tentang benda-benda surga dalam al-Ghāsyiyah/88: 13 dan 14. Al-Raghīb al-Iṣfahānī, Al-Mufradàt fì Gharīb al-Qur'ān, jilid 1, 526. Kata mawdū juga diartikan dengan tema, karena seseorang yang mau menulis dia akan meletakkan topik pembahasan agar tulisan terarah. Kata ini juga dimaknai dengan objek. Dalam ilmu tafsir ditemukan istilah tafsir mawdī $\grave{\imath}$, yaitu tafsir yang dikaji berdasarkan tema-tema tertentu. Lih. Abū al-Fạ̣l Jamāl al-Dīn Muḥammad Mukram ibn Manẓūr, Lisān al-Arab (Beirut: Dār al-Fikr, t.th.), jilid 8, 396-398; Abū alHusayn Aḥmad ibn Fāris ibn Zakarīyā, Mu jam Maqāyis al-Lughah (Beirut: Dār al-Jail, 1991 M.), jilid 6, 117.

6 Menurut penulis, kesadaran inilah yang harus dimiliki oleh kaum Muslim bahwa sosialisasi ajaran-ajaran Islam tidak akan dapat diseragamkan dari satu tempat ke tempat yang lain. Jika hal ini belum disadari secara benar maka akan mudah terjadi ketegangan-ketegangan sosial.

7 'Alī Akbar al-Ḥāirī, "Hayāt al-Syahīd al-Șadr" dalam Muḥammad Bāqir alȘadr, Durūs fì 'Ilm al-Ușūl (Qum: Majma' al-Fikr al-Islāmī, 1419 H), cet. II, 23. Lih. juga Lajnah al-Ta'lif wa al-Tahqīq, Syuhadä' al-Ilm wa-al-Fadìlah $f$ al-'Irāq (N.p.: al-Mu'awwanah al-Tsalafiyyah li al-Jam' al-Ā'lamī li Ahl al-Bayt, 
$1426 \mathrm{H})$, cet. I, 255.

8 Nama ibunya tidak pernah disebutkan dalam berbagai sumber. Ia adalah putri Ayatullah 'Abd al-Ḥusayn 'Alī Yāsīn merupakan tokoh penting sepeninggal Murtaḍā 'Alī Yāsīn dan memiliki putra-putra yang terkenal dengan keluhuran dan ketaqwaannya. Ketiga saudara ibu Bāqir tersebut adalah Muḥammad Riḍā 'Alī Yāsīn, Rāẹī 'Alī Yāsīn dan Murtaḍā 'Alī Yāsīn. Lih. 'Alī Akbar al-Hāèrīi, "Hayāt al-Syahīd al-Ṣadr” dalam Muhammad Bāqir al-Șadr, Durūs fì 'Ilm al-Ușūl 23.

9 Menurut teman sekolahnya, Muhammad 'Alī al-Khalīlī, sejak pertama menjadi siswa di sekolah tersebut kecerdasan Bāqir menjadi sasaran perhatian dan keingintahuan guru-gurunya, sehingga banyak di antara temannya yang meniru cara jalannya, cara bicara dan cara duduknya di kelas. Kisah pengalaman sejenis ini selalu ditemukan dalam biografi Bāqir baik terkait dengan tingkat intelektualnya, kepribadian, maupun hubungan sosialnya. Lebih jelas riwayatriwayat tersebut baca 'Alī Akbar al-Hāinìi, "Hayāt al-Syahīd al-Ṣadr" dalam Muhammad Bāqir al-Ṣadr, Durūs fì 'Ilm al-Ușül, 27-35. Menurut penulis, tidak ditemukannya riwayat yang mengritik atau pendapat yang kontra dengannya dikarenakan nama dan jasa-jasa Bāqir sengaja dilenyapkan oleh rezim Saddam Husain, sehingga para penulis biografi tersebut adalah murid-murid atau para pendukungnya.

10 'Abd al-Jabbār al-Rifā'ī, Manhaj al-Syahīd al-Sadr fì Tajdìd al-Fikr al-Islāmī (Beirut: Dār al-Fikr, 2001 M), 19. Lih. juga 'Alī Akbar al-Hā’irī, "Hayāt alSyahīd al-Ṣadr" dalam Muḥammad Bāqir al-Ṣadr, Durūs fì 'Ilm al-Ușūl, 24.

${ }^{11}$ Najf ialah sebuah kota di negara Irak yang terletak kira-kira 160 km di selatan Baghadad dan merupakan ibu kota propinsi Najf. Kota yang terletak dekat dengan kota Sasanid, bagian tengah dari Bih-Kavad Persia ini merupakan tempat bersejarah Syīah dan pusat kekuatan politik Irak. Di kota ini pula dipercaya terdapat makam 'Alī bin Abī Ṭālib sepupu sekaligus menantu Rasulullah. Najf bagi kaum Syí'ah tak ubahnya Universitas al-Azhar di Kairo Mesir bagi kelompok Sunnī. Pembahasan tokoh-tokoh Syī'ah, terutama di Irak tidak akan bisa dilepaskan dari pemaparan tentang Najf terutama Hauzah alIlmiyah-nya. Diakses dari Wikipedia.org/wiki/najaf, tanggal 27 Februari 2008. Lih. juga, Joyce N. Wiley, The Islamic Movement of al-Qur'än in Shi'as, h. 7-8.

${ }^{12}$ Abū al-Qāsim al-Khūi dilahirkan di Khuwī, Azarbayjan, 15 Rajab 1317 H. bertepatan dengan 19 November 1899 M. dan menghembuskan nafas terakhir di Kūfah tanggal 8 Agustus 1992. Ia adalah tokoh terkemuka, khususnya di dunia Syī'ah, dalam bidang usūl al-fiqh. Hampir seluruh ulama Syī'ah berguru kepadanya. Di samping uṣūl al-fiqh, al-Khū'ì juga menelaah dan mengritisi sejarah al-Qur'ān. Ia merevisi berbagai kritik dan topik-topik kontroversial seputar kesucian teks yang kurang mendapat perhatian sarjana Muslim. Lih. Jurnal Turatsuna, vol. III, no.21, tahun 1426 H., 385; 'Alī Akbar al-Hā’irī, "Hayāt al-Syahīd al-Ṣadr" dalam Muhammad Bāqir al-Ṣadr, Durūs fì 'Ilm alUșūl, 26.

${ }^{13}$ Beberapa sumber menjelaskan bahwa sebelum bertemu kedua guru tersebut, Bāqir al-Ṣadr dengan segala kemampuan yang dimilikinya telah memelajari 
sendiri, autodidak, beberapa kajian usul fiqh, antara lain kitab Rasāil, Makāsib dan Kifāyah 'alá al-Máālim. Ia menekuninya sejak pertama kali masuk di Najf 1365 H./1945 M. (usia 12 tahun). Lih. 'Abd al-Jabbār al-Rifā'ì, Manhaj alSyahid al-Sadr fì Tajdìd al-Fikr al-Islāmī, 19-20; Sayyid Kamal, Tajārub al'Ulamä' fì 'Ușūr al-Ghaybah (Qum: Mu'assasah Anșarīyah, 2006 M.), cet. I, 490.

${ }^{14}$ Dalam hal ini Bāqir pernah mengatakan kepada muridnya, al-Hāīrī, "Sungguh, sebelum masa baligh saya selalu taqlid al-Qur’ān kepada al-marhūm Muhammad Riḍa 'Alī Yāsīn, dan ketika masuk usia baligh saya tidak taqlid al-Qur'ān kepada siapa pun (sudah menjadi mujtahid)." 'Alī Akbar al-Hāàirī, "Hayāt al-Syahīd alȘadr” dalam Muhammad Bāqir al-Ṣadr, Durūs fì 'Ilm al-Ușūl, 25 dan 47.

${ }^{15}$ Penggalian teori-teori tersebut dengan cara memersilahkan al-Qur'ān dan al-Sunnah berbicara dengan sendirinya. Lih. Bāqir al-Șadr, Al-Madrasah alQur'ānīyah, 23; Lih. juga 'Abd al-Jabbār al-Rifā‘ī, Manhaj al-Syahìd al-Ṣadr fī Tajdìd al-Fikr al-Islämī, 67.

${ }^{16}$ Terkait dengan ini Bāqir hanya membagi dua istilah tajzì̄ dan mawdū Kedua istilah ini disebutnya dengan al-ittijāh. Artinya, ada dua istilah yang nampaknya tidak dibedakan secara terperinci oleh Bāqir. Hal ini bisa dilihat ketika dalam Al-Madrasah al-Qur'ānīyah kita menemukan istilah ittijāh, tetapi ketika murid Bāqir yaitu Bāqir al-Hākim mengutipnya secara langsung dalam kitab 'Ulūm al-Qur'ān ia memakai istilah manhaj. Lih. Bāqir al-Ṣadr, Al-Madrasah al-Qur'ānīyah, 19; dan Bāqir al-Hākim, 'Ulūm al-Qur'ān, 345. Salah satu tokoh yang membedakan kedua istilah tersebut adalah 'Alī Iyāzī. Menurutnya, manhaj adalah cara-cara yang digunakan mufassir dalam menjelaskan makna lafaz sedangkan ittijāh adalah sikap mufassir, pandangan, madzhab dan kecenderungannya ketika menafsirkan ayat. Lih. Muhammad 'Alī Iyāzì, al-Mufassirūn Hayātuhum wa-Manhajuhum, 31-32.

${ }^{17}$ Bāqir al-Ṣadr, al-Madrasah al-Qur'ānìyah, 35-36; Bāqir al-Hākim, 'Ulūm alQur'àn, 345-346.

18 Sunan al-Tirmidzī, "Bab Tsawāb al-Qur'ān” nomor Hadīts 14 dan Sunan al-Dārimì dalam "Bab Faḍail al-Qur’ān”. Menurut al-Tirmidzī, Hadīts diriwayatkan dari sahabat Alī ibn Abī Ṭālib dan dinilai sebagai ḥadīts ḥasan.

${ }^{19}$ Bāqir al-Ṣadr, Al-Madrasah al-Qur'ānīyah, 35-36; Bāqir al-Hākim, 'Ulūm alQur'ān, 345-346; Bāqir Bārī, Fiqh al-Nazarīyah 'ind al-Syahìd al-Sadr, 31-33.

${ }^{20}$ Bāqir al-Șadr, Al-Madrasah al-Qur'ānīyah, 36.

${ }^{21}$ Muhammad 'Alī Riḍā, Durūs fì al-Manāhij wa al-Ittijāhāt al-Tafsīrīyah lilQur'ān (Qum: Markaz al-Ālamī li al-Dirāsāt al-Islāmīyah, 1324 H.), 312.

22 Sunan al-Tirmidzì, "Bab Tsawāb al-Qur'ān” nomor Hadīts 14 dan Sunan al-Dārimī dalam "Bab Faḍāil al-Qur'ān”. Menurut al-Tirmidzī, Hadīts diriwayatkan dari sahabat Alī ibn Abī Ṭālib dan dinilai sebagai ḥadīts hasan.

${ }^{23}$ Para ulama memberikan definisi metode mawd $\bar{u} \hat{\imath}$ dengan beragam redaksi, antara lain: pertama, ilmu yang membahas tema-tema al-Qur'ān yang semakna atau satu tujuan dengan cara mengumpulkan ayat-ayat al-Qur'ān yang tersebar (terpisah-pisah), menganalisisnya dengan cara dan syarat-syarat tertentu untuk 
menjelaskan maknanya, mengeluarkan unsur-unsur kandungannya kemudian mengaitkannya sehingga menjadi satu tema; kedua, menjelaskan tema dari ayat-ayat al-Qur'ān dalam satu QS. atau beberapa surah; ketiga, metode yang digunakan mufassir untuk menyingkap maksud Allah yang terdapat di dalam tema-tema al-Qur'ān yang ia telah ditetapkan dan beberapa tema yang ia gunakan untuk menjelaskan aspek hidayah al-Qur'ān dan bentuk kemu 'jizatannya. Lih. Muștafā Muslim, Mabāhits fì al-Tafsīr al-Mawd̄̄ì (Damaskus: Dār al-Qalam, 1989), 16; dan Ziyād Khalīl Muḥammad al-Daghāmīn, Manhajīyāt al-Bahts fì

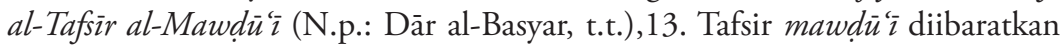
oleh Quraish Shihab seperti menyodorkan kotak berisi hidangan yang telah dipilih dan disiapkan kadar dan ragamnya, sebelum para tamu tiba. Yang memilih, memilah dan menetapkan porsi adalah tuan rumah sehingga para tamu langsung bisa menikmati hidangan tanpa susah payah memersiapkannya sendiri. M. Quraish Shihab, Wawasan al-Qur'ān (Bandung: Mizan, 1996), xii.

${ }^{24}$ Kesimpulan ini tidak sama dengan tokoh maw $\bar{u}_{\bar{u}} \grave{\imath}$ lain yang menyatakan bahwa meskipun metode tafsir mawdūi adalah baru tetapi benihnya sudah ditemukan sejak masa Rasulullah. Lih. Bāqir al-Ṣadr, al-Madrasah al-Qur'ānīyah, 19-25.

${ }^{25}$ Pendapat serupa juga dilontarkan oleh salah satu sarjana Malaysia yang dalam tulisannya banyak merujuk kepada Bāqir yaitu al-Daghāmīn, dalam Manhajīyāt al-Baḥts fì al-Tafsìr al-Mawdū̄̄, 17-19. Lebih detail baca Abdullāh Darrāz, Al-Naba' al-'Azìm (Mesir: Maṭba'ah al-Sa ādah, 1960), 159; lih. juga Muștafā Muslim, Mabähits fì al-Tafsìr al-Mawdū ‘̀, 35; 'Abd al-Sattār Sa'īd, Al-Madkhal ilá al-Tafsìr al-Mawdūī (Kairo: Dār al-Tawzī wa-al-Nasy al-Islāmīyah, 1991) cet. II, 28; Șalāḥ 'Abd al-Fattāh al-Khālidī, Al-Tafsīr al-Mawdüì Bayna al-Nazarīyah wa-al-Taţbìq (Yordan, Dār al-Nafā̀is, 1997), 57; Muhammad al-Ghazālī, Nahww al-Tafsìr al-Mawdū̄̄i (Kairo: Dār al-Syurūq, 1995), cet. I, 241-246.

${ }^{26}$ Bāqir al-Sadr, Al-Madrasah al-Qur'ānīyah, 27.

${ }^{27}$ Bāqir al-Ṣadr, al-Madrasah al-Qurāañyah, 31-32.

${ }^{28}$ Bāqir al-Hakīm, 'Ulūm al-Qur'ān, h. 347.

${ }^{29}$ Bāqir al-Hakīm, 'Ulūm al-Qur'ān, 347.

${ }^{30}$ Sebatas penelitian penulis, inilah harapan awal penekanan min al-wāqi iláal-nașs yang ditawarkan oleh Bāqir. Jika ternyata pada akhirnya ia juga menonjolkan subjektifitasnya itu persoalan individual Bāqir.

${ }^{31}$ Karena rumusan ini adalah hasil kesimpulan penulis dari buku Bāqir dan keterangan muri-muridnya, maka penomoran tahapan penafsiran tersebut bisa berubah-ubah.

${ }^{32}$ Bāqir al-Ṣadr, Al-Islām Yaqūd al-Hayāh (Qum: Markaz al-Abhāts wa al-Dirāsāt al-Takhașsuṣiyah lil-Syahīd al-Ṣadr, 1979 M.), 32; Bāqir al-Ṣadr, Al-Insān alMu'așir wa-al-Musykilah al-Ijtimã ìyah, 40; lih. juga Sayyid Quṭb, Al-'Adālah al-Ijtimā' ì fì al-Islām (Mesir: Dār al-Kātib al-'Arabī, t.th.), 9-10.

${ }^{33}$ Bāqir al-Ṣadr, Al-Islām Yaqūd al-Hayāh, 33. Inilah salah satu kelebihan agama Islam yang tidak dimiliki oleh agama Samawi lainnya, sebagaimana pengakuan dari Louis Awadh yang dikutip oleh Muhammad al-Ghazālī bahwa kekuatan Islam terletak pada perhatiannya terhadap masalah-masalah kehidupan seperti 
halnya perhatiannya terhadap masalah spiritual dan rohani. Lih. Muhammad alGhazālī, Al-Islām wa-al-Tãquàt al-Mu'atțalah (Kairo: Dār al-Kutub al-Hadītsah, 1964 M.), 108.

${ }^{34}$ Bāqir al-Ṣadr, Al-Madrasah al-Qur'ānīyah, 29.

${ }^{35}$ Bāqir al-Ṣadr, Al-Sunan al-Târìkhìyah fì al-Qur'ān, 36; dan Bāqir Bārī, Fiqh Nazarìyah inda al-Syahid al-Sadr, 32.

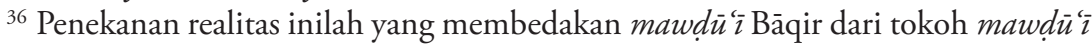
lainnya. Al-Kūmī, al-Farmāwī, al-Sattār juga murid dan rekannya yang lain tidak menekankan pembacaan realitas sebagai prosedur awal. Mereka menjadikan penentuan tema juga sebagai langkah awal tetapi harus berawal dari teks alQur'ān bukan realitas.

${ }^{37}$ Suharsini Arikunto, Manajemen Penelitian, cet.V, 22; John W. Creawell, Reseach Design: Qualitative \& Quantitative Approaches (Thousand Oaks: Sage Publication, 1994 M), 12; Anton Bakker, Metodologi Penelitian Filsafat (Yogyakarta: Kanisius, 1992 M.), 45.

${ }^{38}$ Istilah dialog (al-hiwār) tawaran Bāqir yang tidak ditemukan pada al-Farmāwī dan lainnya. Meski jika diperhatikan penjelasan rinci al-Sattār tidak jauh beda dari maksud Bāqir, namun menurut penulis, ungkapan "mufassir ibarat peserta dialog yang aktif” yang tertulis secara eksplisit dalam kitab Bāqir dapat membawa pengaruh lebih besar kepada mufassir atas posisinya di hadapan teks daripada tanpa ada penjelasan sama sekali sebagaimana yang ditemukan dalam buku al-Farmāwī.

${ }^{39}$ Bāqir al-Ṣadr, Al-Madrasah al-Qur'ānīyah, 31. Bāqir mengutip ungkapan sahabat 'Alī ibn Abī Țālib dalam Nahj al-Baläghah, khutbah ke 158, yang mengatakan dzälik al-Qur'än fastantiqüh (ajaklah al-Qur'ān itu berbicara).

${ }^{40}$ Bāqir al-Ṣadr, Al-Madrasah al-Qur'änīyah, h.34.

${ }^{41}$ Maksudnya, mufassir tidak boleh memaksakan asumsi awal mufassir ketika memahami ayat-ayat al-Qur'ān. Mufassir harus berupaya menggali makna alQur'ān seobjektif mungkin dengan berusaha membuang pra anggapan yang melingkupinya atau paling tidak meminimalisir subjektifitasnya.

${ }^{42}$ Alasan yang menguatkan mereka untuk lebih memilih prinsip min al-nașs ilā al$w a ̄ q i$ ' adalah keyakinan atas kesempurnaan al-Qur'ān. Oleh karena itu, konsepkonsepnya yang terkait tema-tema tertentu harus dikeluarkan atau disuguhkan kepada masyarakat.

${ }^{43}$ Al-Daghāmīn, Manhajīyat al-Bahts fì al-Tafīir al-Mawdūì̄, 28.

${ }^{44}$ Hassan Hanafī, al-Dìn wa-Tsawrah fì Miṣr, vol.VII, tahun 1952-1981, 106. Kemudian ia mengutip QS. al-Ra'd/13 ayat 17 yang artinya: “... Adapun buih itu akan hilang sebagai sesuatu yang tidak ada harganya, sedangkan yang bermanfaat kepada manusia akan tetap di bumi."

${ }^{45}$ Hasan Hanafi, Islam in the Modern World, vol. II, 211. 